різних жанрів, семіотичних кодів і функціональних стилів. Герменевтика текстів базується на таких типах мовних девіацій: 1. Помилки, які становлять суттєві і змістові відхилення від змісту оригіналу. 2. Помилки, які призводять до неточного відтворення смислу оригіналу, але не спотворюють його повністю. 3. Помилки, які не порушують загального змісту оригіналу, але знижують якість тексту перекладу внаслідок відхилення від стилістичних норм мови перекладу, використання маловживаних у певному тексті одиниць, зловживання запозиченнями тощо. 4. Порушення обов'язкових норм мови перекладу, які не впливають на еквівалентність перекладу, але свідчать про недостатнє володіння перекладачем певною мовою чи про його невміння подолати вплив мови оригіналу. Помилки цього роду надають підстави говорити про загальномовну культуру й грамотність перекладача.

\title{
Література:
}

1. Коптілов В. Теорія і практика перекладу : навчальний посібник. Київ : Юніверс, 2002. 280 с.

2. Корунець I. В. Теорія і практика перекладу (аспектний переклад) : підручник. Вінниця : Нова книга, 2001. 448 с.

DOI https://doi.org/10.30525/978-9934-26-114-5-57

\section{ОСНОВНІ НАПРЯМИ ФОРМУВАННЯ АНГЛОМОВНОЇ ФОНЕТИЧНОЇ КОМПЕТЕНТНОСТІ МАЙБУТНІХ УЧИТЕЛІВ ПОЧАТКОВОЇ ШКОЛИ}

\author{
Моляка I. B. \\ аспірантка кафедри педагогіки й психологї \\ Глухівський національний педагогічний університет \\ імені Олександра Довженка \\ м. Глухів, Україна
}

Сучасність педагогічного простору має нині новий виклик дистанційне навчання, яке поперемінно чергується 3 офлайн режимом роботи закладів освіти. До цього вчені й педагоги початкової освіти розробляли методи й підходи в діяльності нової української школи, маючи на меті, підготувати покоління вчителів, які зможуть реалізувати основні цілі навчання у початковій школі - формування 
відповідальних, самостійних, всебічно розвинених і ерудованих учнів [1]. Попри зміни у формі навчання, ключові завдання й виклики залишаються незмінними й потребують додаткової уваги. У зв'язку 3 упровадженням нових навчальних програм початкової освіти виникла необхідність переглянути вимоги до формування фонетичної компетентності вчителів початкової школи.

Проблема формування фонетичної компетентності була предметом багатьох досліджень, а саме питання теоретичної та практичної фонетики англійської мови висвітлено у працях В. Д. Аракіна, В. А. Васильєва, М. П. Дворжецької, Н. Д. Лукіної, Г. П. Торсуєва та ін.; проблемами порівняльної типології фонетичних систем української та англійської мов займались М. М. Галицька, I. В. Корунець, В. I. Кушнерик, О. І. Стеріополо та ін.; методичні особливості формування іншомовної фонетичної компетентності, зокрема у початковій школі, висвітлені у працях С. Ю. Ніколаєвої, С. В. Романа, О. Б. Бігич, О. О. Коломінової, Н. Ф. Бориско та ін.

Англомовна фонетична компетентність як складова іншомовної комунікативної компетентності майбутніх учителів початкової школи відіграє важливу роль не тільки у формування професіонала - вчителя англійської мови, а у формуванні свідомої особистості, яка може використовувати іноземні мову як засіб спілкування, пошуку, наукового дослідження тощо.

Варто пам'ятати, що основними підходами навчання англійської вимови $є$ імітативний та аналітико-імітативний: учні повторюють звуки за вчителем та вчаться правильно говорити їх у нових, аналогічних словах [2]. Тому вчитель має досконало володіти знаннями з фонетики англійської мови та вміти використовувати відповідні методи та підходи до роботи з учнями початкової школи.

Не дарма С. Ю. Ніколаєва відводить важливу роль принципу комунікативності на уроках англійської мови. Вона пише: «...вчитель повинен керуватись принципом комунікативності, пам'ятати, що він приходять на урок не для того, щоб вивчати нові звуки, а з метою навчитись спілкуванню іноземною мовою. Тому введення звука краще починати зі створення ситуації, що зумовлює багаторазову вимову нового звука» [3, с. 96].

I. О. Пінчук у статті «Англомовна компетентність як складник системи професійної підготовки майбутніх учителів початкових класів» акцентує увагу на важливості формування у вчителів початкової школи специфічних професійно-предметних, індивідуально-психологічних i комунікативних якостей порівняно з учителем основної та старшої школи [4]. 
Англомовна фонетична компетентність учителів початкової школи забезпечує успішність викладання англійської мови та закладає основи для правильного вивчення іноземної мови у майбутньому, а також покращує репутацію України як країни, що надає якісну освіту та $є$ привабливою для студентів.

Актуальними та новими $є$ такі напрями формування англомовної фонетичної компетентності майбутніх учителів початкової школи:

1) перевага комунікативного підходу до навчання англійської мови (орієнтація учня на вивчення нового матеріалу не для запам'ятовування, а для практичного використання на уроці або у повсякденному житті);

2) розвиток білінгвальної педагогічної освіти, основними завданнями якої $є$ формування у студентів загальної й професійної білінгвальної компетентності та забезпечення наявності у вчителів інтегративних знань. На сьогодні обговорюється й проблема розробки інтегративних курсів. За цих обставин особливо актуальним науковометодичним завданням є обгрунтування й визначення оптимальних підходів до навчання фонетики англійської мови засобами порівняльного аналізу англійської й української мов, що забезпечить належний рівень формування англомовної фонетичної компетентності вчителів початкової школи;

3) удосконалення системи самостійної підготовки студентів (виконання креативних завдань, спрямованих на формування вмінь $\mathrm{i}$ навичок іншомовної комунікації та фонетичної компетентності).

Отже, фонетичну компетентність розглядають як здатність до правильного артикуляційного та інтонаційного висловлювання своїх думок i розуміння мовлення інших, яка базується на відповідних фонетичних навичках та знаннях. Саме від рівня сформованості вимовних навичок, від обсягу отриманих та засвоєних знань та динамічної взаємодії цих компонентів залежить ефективність формування фонетичної компетентності майбутніх учителів початкової школи. Перспективи подальшого розвитку вбачаємо у дослідженні особливостей формування фонетичної компетентності вчителів початкової школи засобами порівняльного аналізу фонетичних систем англійської й української мов.

\section{Література:}

1. Державний стандарт початкової освіти. Київ. 2018. URL: https://mon.gov.ua/ua/osvita/zagalna-serednya-osvita/derzhavni-standarti (дата звернення: 03.06.2021). 
2. Панова Л. С., Андрійко І. Ф. Методика навчання іноземних мов у загальноосвітніх навчальних закладах. Київ: Академія, 2010. 327 с.

3. Ніколаєва С. Ю. Методика викладання іноземних мов у середніх навчальних закладах. Київ: Ленвіт, 2002. 328 с.

4. Пінчук I. О. Англомовна компетентність як складник професійної підготовки майбутніх учителів початкових класів. Young Scientist. 2014. № 12. С. 177-180.

DOI https://doi.org/10.30525/978-9934-26-114-5-58

\title{
ЗАСОБИ ЕЛЕКТРОННОЇ ДИДАКТИКИ В МОВНІЙ ПІДГОТОВЦІ ЗДОБУВАЧІВ ВИЩОЇ ОСВІТИ
}

\author{
Нагрибельна I. А. \\ докторка педагогічних наук, \\ професорка кафедри соиіально-гуманітарних дисииплін \\ та інноваиійної педагогіки \\ Херсонська державна морська академія \\ Нагрибельний Б. Я. \\ учитель історії та права НВК № 9 I-III cm. навчання \\ м. Херсон, Украӥна
}

Процес активної модернізація системи вищої освіти в Україні зумовлений низкою чинників. Серед провідних відзначимо такі: соціальний запит на конкурентного випускника вишу; потреба увідповіднення змісту та методів навчання; розширення спектру альтернативних джерел інформації для здобувачів вищої освіти; потреба в розвитку та удосконаленні цифрової грамотності усіх учасників освітнього процесу.

У системі вищої освіти пріоритет означених чинників зумовив оновлення мовної підготовки сучасних здобувачів. Тенденції мовномовленнєвої освіти у виші демонструють виокремлення категорій електронної дидактики та їх активне застосування в освітньому процесі. Так, наприклад, в мовній підготовці здобувачів вищої освіти Херсонської державної морської академії ефективно використовуються засоби цифровізації.

Сучасний арсенал цифрових засобів навчання постійно розширюється та удосконалюється, тому для вибору доцільних саме в мовній освіті маємо оцінити функціонал основних ресурсів. Погоджуємося із 